\title{
PENGAWASAN PERIZINAN TENAGA KERJA ASING
}

\author{
Peko Laksono \\ Fakultas Hukum Universitas Bengkulu \\ pekolaksono@gmail.com
}

\begin{abstract}
This study aims to examine the implementation of the Regional Government in the supervision of Foreign Workers and Law Enforcement of Foreign Workers working in Lebong Regency. This non-doctrinal legal research uses the empirical legal research method, which was carried out in Lebong Regency. The results of the study concluded that (1) Supervision of Foreign Workers in Lebong District was carried out by the Pora Team. However, it did not run optimally due to several factors, namely (a) the lack of the role of the Regional Government in Supervision of Foreign Workers; (b) there is no openness between foreign companies and the Manpower Office regarding the data of Foreign Workers in Bengkulu Province, especially Lebong Regency; (c) lack of supervision from the Foreigners Monitoring Team (Pora Team) in Lebong Regency in checking those in Lebong Regency. (2) Law Number 13 of 2003 concerning employment does not regulate sanctions against illegal TKA but to employers' companies. Arrangements are more for deportations carried out by the immigration department.
\end{abstract}

Keywords: Oversight; Permits; Foreign Workers

\begin{abstract}
Abstrak
Penelitian ini bertujuan untuk mengkaji pelaksanaan Pemerintah Daerah dalam pengawasan Tenaga Kerja Asing di Kabupaten Lebong dan Penegakan Hukum terhadap Tenaga Kerja Asing yang berkerja di Kabupaten Lebong. Penelitian hukum non doktrinal ini menggunakan metode penelitian hukum empiris, yang dilakukan di Kabupaten Lebong. Hasil penelitian meyimpulkan bahwa (1) Pengawasan Tenaga Kerja Asing di Kabupaten Lebong dilakukan oleh Tim Pora. Namun tidak berjalan optimal disebabkan beberapa faktor yaitu (a) kurangnya peran Pemerintah Daerah dalam Pengawasan terhadap Tenaga Kerja Asing; (b) tidak adanya keterbukaan antara perusahaan asing dengan Dinas Ketenagakerjaan mengenai data Tenaga Kerja Asing yang ada di Provinsi Bengkulu khususnya Kabupaten Lebong; (c) kurangnya pengawasan dari Tim Pengawasan Orang asing (Tim Pora) di Kabupaten Lebong dalam melakukan pengecekan terhadap yang ada di Kabupaten Lebong. (2) Undang-Undang Nomor 13 Tahun 2003 tentang Ketenagakerjaan tidak mengatur tentang sanksi terhadap TKA ilegal tetapi kepada perushaan pemberi kerja. Pengaturan lebih kepada deportasi yang dilakukan oleh bagian imigras.
\end{abstract}

Kata Kunci: Pengawasaan; Izin; Tenaga Kerja Asing

\section{PENDAHULUAN}

Perkembangan globalisasi dan industrialisasi saat ini mendorong pergerakan aliran modal dan investasi ke berbagai sendi-sendi kehidupan di penjuru dunia, termasuk di dalam aspek ketenagakerjaan, yang mengakibatkan terjadinya imigrasi penduduk atau pergerakan tenaga kerja antar negara. Dalam mewujudkan tertib hukum di dalam memperkerjakan tenaga kerja untuk meningkatkan mutu tenaga kerja, para pemilik modal sebagai pengusaha perlu membawa serta beberapa tenaga kerja dari negara asal atau negara lain untuk

Peko Laksono, Pengawasan Perizinan Tenaga Kerja Asing 
bekerja sebagai tenaga kerja. Maka diperlukan suatu perjanjian antar Masyarakat Ekonomi Asean.

Indonesia termasuk salah satu negara dalam Masyarakat Ekonomi Asean (MEA) atau Asean Economic Community (AEC) yang dimulai pada Tahun 2015, bertujuan dibentuknya Masyarakat Ekonomi Asean (MEA) untuk meningkatkan stabilitas perekonomian di kawasan ASEAN, serta diharapkan mampu mengatasi masalah-masalah di bidang ekonomi antar negara. Pembentukan MEA dilandaskan pada empat pilar. Pertama, menjadikan ASEAN sebagai pasar tunggal dan pusat produksi. Kedua, menjadi kawasan ekonomi yang kompetitif. Ketiga, menciptakan pertumbuhan ekonomi yang seimbang, dan pilar Keempat adalah integrasi ke ekonomi global. ${ }^{1}$ Penyatuan tersebut ditujukan untuk meningkatkan daya saing kawasan, mendorong pertumbuhan ekonomi, menekan angka kemiskinan dan untuk meningkatkan standar hidup masyarakat ASEAN. Integrasi ini diharapkan akan membangun perekonomian ASEAN serta mengarahkan ASEAN sebagai tulang punggung perekonomian di Asia.

Dampak positifnya tersebut dengan adanya MEA, tentu akan memacu pertumbuhan investasi baik dari luar maupun dalam negeri sehingga akan membuka lapangan pekerjaan baru. Sedangkan dampak negatif dari MEA, yaitu dengan adanya pasar barang dan jasa secara bebas tersebut akan mengakibatkan Tenaga Kerja Asing dengan mudah masuk dan bekerja di Indonesia sehingga mengakibatkan persaingan tenaga kerja yang semakin ketat di bidang ketenagakerjaan. ${ }^{2}$

Salah satunya adalah persoalan ketenagakerja asing yang berkerja di Indonesia dari Tahun 2016 sampai januari 2017, yang berjumlah sebanyak 74.183 tenaga asing yang berkerja di Indonesia dengan rinciannya sebanyak 21.271 Tenaga Kerja Asing asal China, 12.490 Tenaga Kerja Asing asal Jepang, 8.424 tenaga asing asal Korea Selatan, dan 5.059 Tenaga Kerja Asing asal India. kemudian 4.138 tenaga kerjaa asal Malaysia, 2.812 Tenaga Kerja Asing asal Amerika Serikat, 2.394 tenaga kerja asal Thailand. Lalu sebanyak 2,483 Tenaga Kerja Asing asal Australia, 3.428 tenaga kerja asal Inggris, 1.748 tenaga kerja asal Singapura, dan 7.684 Tenaga Kerja Asing dari Negara lainya. ${ }^{3}$

Provinsi Bengkulu seperti halnya propinsi lainnya menjadi tujuan bagi Tenaga Kerja Asing (TKA) karena tumbuhnya sektor pertambangan. Jumlah Tenaga Kerja Asing di Provinsi Bengkulu tergolong tinggi, yakni 304 (tiga ratus empat)

1 Edy Cahayono, Tenaga Kerja Asing (TKA) Dalam Persepektif Masyarakat Ekonomi Asean (MEA); Peluang Atau Acaman Bagi Sdm Indonesia. Jurnal JBMA Vol. III (2) , September 2016 diunduh Pada Tanggal 25 Oktober 2017.

2http://rizkie-library.blogspot.co.id/2015/09/mea-dan-kebijakan-

ketenagakerjaan.- html,Diunduh Pada Tanggal 25 Oktober 2017, Pukul 21.18. Wib

3http; / Ekonomi.Kompas.Com/Read/2017/07/17/171733726/Jumlah-

Tenaga-Kerja-Asing-Dari-China-Di-Indonesia-Tertinggi-Sejak. Diunduh Pada Tanggal 28 Oktober 2017, Pukul 22.39.Wib

Peko Laksono, Pengawasan Perizinan Tenaga Kerja Asing 
orang data terakhir bulan Juni 2017 oleh Kantor Imigrasi Perwakilan Provinsi Bengkulu.

Dari data tersebut, Tenaga Kerja Asing (TKA) terbanyak berada di Kabupaten Bengkulu Tengah (Benteng) dengan jumlah 149 (seratus empat puluh sembilan) orang. Jumlah ini terbagi di beberapa perusahaan pertambangan seperti 2 (dua) orang di PT Bengkulu Bio Energy, 2 (dua) orang di PT Cipta Buana Seraya, 1 (satu) orang di PT Pixiang Mining, dan 144 (seratus empat puluh empat) orang di PT Kusama Raya Utama. Kemudian terbanyak ke 2 (dua) disusul Kabupaten Lebong terbanyak yakni sebanyak 59 (lima puluh sembilan) orang, yang terbagi menjadi 46 (empat pulu enam) orang bekerja di PT Bangun Tirta Lestari 1 (satu) orang, di PT Energy Sakti Sentosa, 2 (Dua) orang di PT Sinohydro Corp Limited, 6 (enam) orang di PT Tansri Madjid Energi, dan 4 (empat) orang di PT Jambi Resources dan sisanya tersebar di beberapa perusahaan pertambangan di Bengkulu Utara, Kepayang, Kaur dan Mukomuko. 4

Berdasarkan uraian tersebut, penelitian ini bertujuan untuk mengkaji pengawasan perizinan Tenaga Kerja Asing (TKA) dan penegakan hukum terhadap TKA ilegal yang bekerja di wilayah Kabupaten Lebong. Hal tersebut pada dasarnya karena adanya beberapa perusahaan mempekerjakan tenaga kerja asing tanpa memiliki izin masuk ke Indonesia termasuk di wilayah kabupaten Lebong.

\section{METODE PENELITIAN}

Penelitian ini merupakan penelitian hukum empiris yang menggunakan metode pendekatan socio-legal research. Penelitian dilakukan di wilayah Kabupaten Lebong yang berdasarkan data terdapat beberapa perusahaan mempekerjakan tenaga kerja asing. Pengumpulan data menggunakan cara wawancara untuk memperoleh data primer, dan studi kepustakaan untuk mengumpulkan data sekunder. Penentuan sampel dalam penelitian ini menggunakan metode purposive sampling. Sampel yang ditentukan untuk menjadi responden dalam penelitian ini adalah (1)Dinas Ketenagakerjaan dan Transmigrasi Provinsi Bengkulu (Kepala Seksi Penempatan dan pengawasan tenaga kerja asing dinas ketenagakerjaan Provinsi Bengkulu, dan pengawas ketenagakerjaan Provinsi Bengkulu ); (2) Dinas Ketenagakerjaan dan Transmigrasi Kabupaten Lebong (Kasi perluasaan pengembangan kesempatan kerja Transmigrasi Kabupaten Lebong dan Staf Bidang ketenagakerjaan dinas ketenagakerjaan dan Transmigrasi kabupaten lebong); (3) Tim PORA (Pengawasan Orang Asing). Selanjutnya analisi data menggunkan metode analisis yuridis kualitatif menggunakan kerangka berpikir deduktif dan indukatif.

\section{HASIL PENELITIAN DAN PEMBAHASAN}

${ }^{4}$ http: / harianrakyatbengkulu.com/ver3/2017/07/26/TKA-masihdidomininasi-asal-cina-penyebaran-TKA-didominasi-sektor-pertambangan, diunduh pada tangal 29 September 2017, Pukul 22.12.

Peko Laksono, Pengawasan Perizinan Tenaga Kerja Asing 


\section{Pelaksanaan Pengawasan Tenaga Kerja Asing Oleh Pemerintah Daerah Di Kabupaten Lebong}

Dasar Hukum Pemerintah Daerah Dalam Melaksanakan Pengawasan Tenaga Kerja Asing:

1. Undang-Undang Nomor 6 Tahun 2011 tentang Keimigrasian

Pengaturan yang berkaitan dengan pengawansan terhadap Orang Asing diatur dalam Undang-Undang Nomor 6 Tahun 2011 tentang Keimigrasian, Pengawasan terhadap Orang Asing tidak hanya di lakukan pada saat mereka masuk, tetapi juga selama mereka berada di wilayah indonesia, termasuk kegiatannya. Berkaitan dengan Pelaksanaan Pengawasan terhadap Tenaga Kerja Asing yang diatur dalam Pasal 66 sampai Pasal 73 Undang-Undang Nomor 6 Tahun 2011 tentang Keimigrasian. Ketentuan mengenai pengawasan terhadap Orang Asinsebagaiman dimaksud dalam pasal 68 ayat (1) huruf b, huruf c,huruf d, dan huruf e tidak diberlakukan terhadap Orang Asing yang berada di wilayah Indonesia dalam rangka tugas diplomatik.

2. Undang-Undang Nomor 13 Tahun 2003 tentang Ketenagakerjaan

Pengaturan yang berkaitan dengan Pelaksanaan Pengawasan terhadap Tenaga Kerja Asing yang diatur dalam Undang-Undang Nomor 13 Tahun 2003 tentang Ketenagakerjaan, dalam ketentuan Pasal 176, yang menyatakan bahwa "Pengawasan ketenagakerjaan dilakukan oleh pegawai pengawas ketenagakerjaa yang mempunyai kompetensi dan independen guna menjamin pelaksanaan peraturan perundang-undangan ketenagakerjaan".

Dengan ketentuan pasal tersebut dapat diartikan bahwa Tim Pora mempunyai tugas memberikan saran dan pertimbangan kepada intansi atau lembaga pemerintah terkait, mengenai hal yang berkaitan dengan pengawasan orang asing. Berbicara mengenai pengawasaan ketenagakerjaan dilaksanakan melalui tiga pendekatan, yaitu preventif, edukatif, dan refrensif yustisia.

Pada dasarnya kedua cara itu ditempuh sangat bergantung dari tingkat kepatuhan masyarakakat (pengusaha, pekerja/buruh, dan serikat pekerja/serikat buruh) terhadap ketentuan hukum ketenagakerjaan. Tindakan preverentif edukatif dilakukan jika memungkinkan dan masih adanya kesadaraan masyarakat untuk mematuhi hukum. ${ }^{5}$

3. Undang-Undang Nomor 23 Tahun 2014 tentang Pemerintah Daerah

Pengaturan yang berkaitan dengan Pelaksanaan Pengawasan terhadap Tenaga Kerja Asing terdapat dalam Lampiran Undang-Undang Nomor 23 Tahun 2014 tentang Pemerintah Daerah yang menyatakan bahwa kewenangan pengawasan ketenagakerja berada di bawah Pemerintah Provinsi, oleh karena itu seluruh pengawasan ketenagakerjan yang memiliki wewenang pengawasan dan segala hal berkaitan dengan ketenagakerjaan, termasuk keberadaan Tenaga Kerja Asing (TKA), telah berpindah kewenagan ke provinsi. Adanya Tenaga Kerja Asing (TKA), yang mana telah menjadi kewenagan Provinsi dalam mengawasi TKA, maka pelaksaaan pengawasan tersebut dibentuknya Tim Pora sebagai

${ }^{5}$ Loc., Cit.

Peko Laksono, Pengawasan Perizinan Tenaga Kerja Asing 
instansi atau lembaga pengawasan yang dilakukan di Kabupaten Kota terhadap TKA sebagaimana dimaksud dalam ketentuan Peraturan Menteri Hukum dan Hak Asasi Manusia Republik Indonesia Nomor 50 Tahun 2016 tentang Tim Pengawasan Orang Asing.

4. Peraturan Pemerintah Nomor 31 Tahun 2013 tentang Peraturan Pelaksanaan Undang-Undang Nomor 6 Tahun 2011 tentang keimigrasian.

Pengaturan yang berkaitan dengan Pelaksanaan Pengawasan terhadap Tenaga Kerja Asing yang diatur dalam Pasal 194 sampai Pasal 201 Peraturan Pemerintah Nomor 31 Tahun 2013 tentang Peraturan Pelaksanaan UndangUndang Nomor 6 Tahun 2011 tentang keimigrasian. Ketentuan lebih lanjut mengenai tim pengawasan Orang asing diatur dengan peraturan menteri.

5. Peraturan Presiden Nomor 72 Tahun 2014 tentang Penggunaan Tenaga Kerja Asing Serta Pelaksanaan Pendidikan Dan Pelatihan Pekerja Pendamping Pengaturan yang berkaitan dengan Pelaksanaan Pengawasan terhadap Tenaga Kerja Asing yang diatur dalam Peraturan Presiden Nomor 72 Tahun 2014 tentang Pengunaan Tenaga Kerja Asing Serta Pelaksanaan Pendidikan dan Pelatihan Pekerja Pendamping. Dalam Pasal 15 menjadi kewenangan dimana sejak haidrnya 2017 Undang-Undang Nomor 23 Tahun 2014 tentang Pemerintah Daerah, penyelengaraan pengawasaan ketenagakerjaan yang semula menjadi urusan Pemerintah Daerah Kabupaten/Kota dialihkan menjadi urusan Pemerintah Provinsi.

6. Peraturan Menteri Ketenagakerjaan Nomor 16 Tahun 2015 tentang Tata Cara Penggunaan Tenaga Kerja Asing

Menurut Pasal 1 angka 1Tenaga Kerja Asing yang selanjutnya disingkat TKA, adalah warga negara asing pemegang visa dengan maksud bekerja di Wilayah Indonesia. Dalam pelaksanaan Pengawasan terdapat dalam ketentuan Pasal 60 yang menyatakan bahwa:"Pengawasan terhadap pemberi kerja Tenaga Kerja Asing dilakukan oleh Pegawai Pengawas Ketenagakerjaan sesuai dengan ketentuan Peraturan Perundang-undangan". Pengawasaan ketenagakerjaan ditempuh dengan memberdayakan kelembagaan yang ada, seperti Lembaga Kerja Sama (LKS) bipartit di setiap perusahaan. Dalam hal ini peranan serikat pekerja/serikat buruh sangatlah strategis dalam membantu pengawasaan pelaksanaan ketentuan ketenagakerjaan di semua sektor. Di samping itu, juga tumbuhnya Lembaga Swadaya Masyarakat (LSM) kiranya dapat didorong untuk melakukan control secara tidak langsung. Mereka dapat mengkritisi setiap peristiwa pelanggaran ketetntuan ketenagakerjaan yang merugikan pekerja/buruh atau masyarakat. ${ }^{6}$

7. Peraturan Menteri Hukum dan Hak Asasi Manusia Republik Indonesia Nomor 50 Tahun 2016 tentang Tim Pengawasan Orang Asing.

Pengaturan yang berkaitan dengan dibentuknya Tim Pengawasan Orang Asing berdasarkan Peraturan Pemerintah Nomor 31 Tahun 2013 tentang Peraturan

${ }^{6}$ Loc., Cit.

Peko Laksono, Pengawasan Perizinan Tenaga Kerja Asing 
Pelaksanaan Undang-Undang Nomor 6 Tahun 2011 tentang Keimigrasian, yang diatur dalam Pasal 194 sampai Pasal 201. Ketentuan lebih lanjut mengenai pembentukan Tim Pengawasan Orang Asing diatur dengan Peraturan Menteri. Maka lahirnya Peraturan Menteri Hukum dan Hak Asasi Manusia Republik Indonesia Nomor 50 Tahun 2016 tentang Tim Pengawasan Orang Asing. Pembetukan Intansi atau lembaga pemerintah yang dikenal dengan Tim Pora tersebut yang mempunyai tugas dan fungsi terkait dengan keberadaan dan kegiatan dalam pengawasan tenaga kerja asing yang berada di Kabupaten Lebong.

8. Peraturan Menteri Nomor PER.02/MEN/III/2008 Tentang Tata Cara Penggunaan Tenaga Kerja Asing.

Peraturan Menteri Nomor PER.02/MEN/III/2008 tentang Tata Cara Penggunaan Tenaga Kerja Asing. Selanjutnya dijelaskan bahwa untuk memenuhi kebutuhan pasar kerja nasional terutama dalam mengisi kekosongan keahlian dan kompetensi di bidang tertentu yang tidak dapat tercover oleh tenaga kerja Indonesia, maka Tenaga Kerja Asing dapat dipekerjakan di Indonesia sepanjang dalam hubungan kerja untuk jabatan tertentu dan waktu tertentu. Mempekerjakan Tenaga Kerja Asing dapat dilakukan oleh pihak manapun sesuai dengan ketentuan kecuali pemberi kerja orang perseorangan. Setiap pemberi kerja yang mempekerjakan Tenaga Kerja Asing wajib memiliki izin tertulis dari menteri atau pejabat yang ditunjuk kecuali terhadap perwakilan negara asing yang mempergunakan Tenaga Kerja Asing sebagai pegawai diplomatik dan konsuler. Ketentuan mengenai jabatan tertentu dan waktu tertentu bagi Tenaga Kerja Asing ditetapkan dengan keputusan Menteri, yaitu Keputusan Menteri Nomor : KEP-173/MEN/2000 tentang Jangka Waktu Izin Mempekerjakan Tenaga Kerja Warga Negara Asing Pendatang.

9. Peraturan Daerah Provinsi Bengkulu Nomor 7 Tahun 2016 tentang Retribusi Perpanjangan Izin Memperkerjakan Tenaga Kerja Asing.

Pengaturan yang berkaitan dengan Pelaksanaan Pengawasan terhadap Tenaga Kerja Asing yang diatur dalam Peraturan Daerah Provinsi Bengkulu Nomor 7 Tahun 2016 tentang Retribusi Perpanjangan Izin Memperkerjakan Tenaga Kerja Asing. Bahwa penguna tenaga kerja asing yang selanjutnya disingkat RPTKA adalah rencana penggunaan tenaga kerja asing pada jabatan tertentu yang dibuat oleh pemberi kerja Tenaga Kerja Asing untuk jangka waktu tertentu yang disahkan oleh menteri atau pejabat yang di tunjuk. Dalam perpanjangan izin memperkerjakan Tenaga Kerja Asing, yang selanjutnya disebut Retribusi perpanjangan IMTA, adalah pungutan atas pemberian perpanjangan IMTA kepada pemberi kerja tenaga kerja asing.

\section{Pelaksanaan Pengawasan Tenaga Kerja Asing Oleh Pemerintah Di Wilayah Propinsi Bengkulu}

Pengaturan yang berkaitan dengan Pelaksanaan Pengawasan terhadap Tenaga Kerja Asing terdapat dalam Lampiran Undang-Undang Nomor 23 Tahun

Peko Laksono, Pengawasan Perizinan Tenaga Kerja Asing 
2014 tentang Pemerintah Daerah, bahwa kewenagan pengawasan ketenagakerja berada dibawah Pemerintah Provinsi, oleh karena itu seluruh pengawasan ketenagakerjan yang memiliki wewenang pengawasan dan segala hal berkaitan dengan ketenagakerjaan, termasuk keberadaan Tenaga Kerja Asing (TKA), Telah berpindah kewenangan provinsi dalam mengawasi TKA. Sebelumnya Pengaturan tersebut diatur dalam ketentuan Undang-Undang Nomor 32 Tahun 2004 tentang Pemerintah Daerah, Sebagaimana di dalam ketentuan Peraturan Pemerintah Republik Indonesia Nomor 38 Tahun 2007 tentang Pembagian Urusan Pemerintah Antara Pemerintah, Pemerintahan Daerah Provinsi, dan Pemerintahan Daerah Kabupaten/Kota. Dengan lahirnya Undang-Undang Nomor 23 Tahun 2014 tentang Pemerintah Daerah, bertujuan untuk mencegah terjadinya penyimpangan terhadap penggunaan tenaga kerja yang dimana Retribusi Daerah merupakan salah satu sumber pendapatan daerah yang penting guna membiayai penyelenggaraan Pemerintahan Daerah, yang dalam hal ini untuk menunjang kualitas tenaga kerja lokal pada salah satu kekhususan penggunaannya Tenaga Kerja Asing (TKA).

Adanya Tenaga Kerja Asing di Propinsi Bengkulu harus melewati tahapantahapan prosedur mengenai Tenaga Kerja Asing yang bisa bekerja di Indonesia khsusnya di Propinsi Bengkulu yang berdasarkan Undang-Undang Nomor 13 Tahun 2003 Pasal 42 dan Pasal 43 bahwa adanya TKA di mungkinkan bekerja di wilayah Indonesia dengan prosedurnya di awali dengan pengajuan Rencana Pengguna Tenaga Kerja Asing (RPTKA) oleh perusahaan berisi mengenai kebutuhaan perusahaan terhadap TKA untuk jenis pekerjaan tertentu dalam waktu tertentu, izin ini di keluarkan oleh menteri ketenaga kerjaan ataupun pejabat yang di tunjuk. dan RPTKA ini merupakan dasar mengeluarkan IMTA (Izin Memperkerja Tenaga Asing) yang salah satu syaratnya adalah KITAS (Kartu Indentitas TKA) sebagai tanda pengenal dari TKA seperti Kartu Tanda Penduduk (KTP) pada Warga Negara Indonesia (WNI). ${ }^{7}$

Landasan utama pengunaan TKA dilaksanakan secara selektip dalam rangka pendayagunaan tenaga kerja Indonesia secara optimal sehingga izin penggunaan TKA di mulai dari Rencana Pengguna Tenaga Kerja Asing (RPTKA) yang merupakan persyaratan untuk mendapatkan izin kerja (IKTA) bagi TKA yang akan di pekerjakan dan sebagai dasar untuk memperoleh IMTA bagi perusahaan yang memperkerjakaan TKA, di dalamnya terdapat syarat lain sehingga hal tersebut bisa di keluarkan antara lain hanya dapat di lakukan untuk pekerjaan tertentu, jabatan tertentu dan dalam waktu tertentu ,memiliki TKI pendamping sebagai transfer teknoloogi dan jabatan yang bisa diduduki oleh TKA ${ }^{8}$.

7 Hasil Wawancara Dengan Dewi Murni Staff Bagian Pengawasan TKA, Dinas Ketenagakerjaan Dan Tranmigrasi Provinsi Bengkulu, Pada tanggal 29 Januari 2018, Pukul 09.30 Wib.

8 Hasil Wawancara Dengan Eni Denti, Staff Bagian Pengawasan Dinas Ketenagakerjaan Dan Tranmigrasi Provinsi Bengkulu, Pada tanggal 29 Januari 2018, Pukul 09.50 Wib.

Peko Laksono, Pengawasan Perizinan Tenaga Kerja Asing 
Di Provinsi Bengkulu jumlah Tenaga Kerja Asing pada akhir bulan Desember 2017 dapat dilihat pada table di bawah ini:

Tabel: Tenaga Kerja Asing Pada Akhir Bulan Desember 2017

\begin{tabular}{|ccc|}
\hline No & Jumlah Tenaga Kerja Asing & Keterangan \\
1 & 175 Orang & Kota Bengkulu \\
2 & 21 Orang & Kabupaten Bengkulu Utara \\
3 & 74 Orang & Kabupaten Lebong \\
4 & 126 Orang & Kabupaten Bengkulu Tengah \\
5 & 2 Orang & Kabupaten Muko-Muko \\
6 & 1 Orang & Kabupaten Kaur \\
7 & 2 Orang & Kabupaten Kepahiang \\
\hline
\end{tabular}

Sumber: Dinas Ketenagakerjaan dan Transmigrasi Provinsi Bengkulu 2017.

Dari table di atas dapat dilihat jumlah Tenaga Kerja Asing yang berada di Provinsi Bengkulu sebanyak 401 (Empat Ratus Satu) orang. Dengan adanya Tenaga Kerja Asing yang berkerja dan berada di Propinsi Bengkulu, Maka dalam dilakukannya pengawasan terhadap semua Tenaga Kerja Asing yang berkerja di Provinsi Bengkulu harus berpedoman dengan aturan peraturan perundangundangan yang berlaku.

Dalam pengawasan Tenaga Kerja Asing di Kabupaten Lebong, Bengkulu Tengah, Bengkulu Utara, adalah kewenangan Provinsi Bengkulu dalam pengawasan Tenaga Kerja Asing. Pengawasan Tenaga Kerja Asing sesuai dengan Undang-Undang Nomor 13 Tahun 2003 Pasal 176 yang menyatakan bahwa: "Pengawasan ketenagakerjaan dilakukan oleh pegawai pengawas ketenaga-kerjaan yang mempunyai kompetensi dan independen guna menjamin pelaksanaan peraturan perundang-undangan ketenagakerjaan".

Hal tersebut dipertegaskan lagi dalam Peraturan Presiden Nomor 72 Tahun 2014 tentang Pengunaan Tenaga Kerja Asing Serta Pelaksanaan Pendidikan dan Pelatian Pekerja Pendamping, dalam Pasal 15 menjadi kewenangan Pemerintah Daerah, penyelengaraan pengawasaan ketenagakerjaan yang semula menjadi urusan Pemerintah Daerah Kabupaten/Kota dialihkan menjadi urusan Pemerintah Provinsi. Peraturan Badan Kepegawaian Negara Nomor 48 tahun 2015 tentag Pelaksanaan Pengalihaan Pegawai Negeri Sipil Daerah Kabupaten/Kota yang menyelengarakan penggawasan ketenagakerjaan menjadi Pegawai Negeri Sipil Daerah Provinsi sehinga semua pengawasan dialihkan status kepegawaianya menjadi pemerintah provinsi yang sebelumnya kewenangan pengawasaan ada di kabupaten/kota masing-masing. ${ }^{9}$

Dalam pelaksanaan pengawasaan terhadap Tenaga Kerja Asing di setiap Kabupaten yang berada di Provinsi Bengkulu, yang menjadi Tim pengawasan TKA dapat melibatkan kepada pengawasan ketenagakerjaan, PPNS (Penyidik Pegawai Negeri Sipil), imigrasi perizinan, penempatan tenaga kerja.

Pelaksanan pengawasan yang dilakukan setiap 1 tahun sekali dan bisa lebih apabila di butukan pemeriksaan lebih lanjut, karena peran Dinas

${ }^{9}$ Hasil Wawancara Dengan Dewi Murni, Op., Cit.

Peko Laksono, Pengawasan Perizinan Tenaga Kerja Asing 
Ketenagakerjaan terhadap TKA ilegal melakukan pembinaan kepada perusahaan pemberi pekerjaan untuk segera mengikuti pesryaratan untuk melakukan pengurusan perizinan, dan dapat pula dilakukan penindakan hukum sesuai dengan Ketentuan dalam Pasal 185 Undang-Undang Nomor 13 Tahun 2003 tentang Ketenaga kerjaan, yang dilakukan oleh Penyidik Pegawai Negeri Sipil, dengan imigrasi dalam melakukan pengawasan TKA ilegal. Pengawasan yang dilakukan oleh dinas ketenaga kerjaan dan tramigrasi di setiap kabupaten yang memperkerjakan Tenaga Asing, apakah hanya menerima laporan atau turun langsung ke lapangan untuk memeriksa Tenaga Kerja Asing. Pegawasan yang dilakukan bisa dengan cara menerima laporan dari Dinas Ketenagakerjaan yang ada di Kabupaten/Kota yang nantinya ditindak lanjuti dengan melakukan pemeriksaan langsung ke perusahaan, pengawasaan ketenagakerjaan memiliki agenda pemeriksaan setiap bulannya.

Pengawasan terhadap pelaksanaan ketenagakerjaan yang dilakukan oleh Dinas Ketenagakerjaan Dan Transmigrasi di Kabupaten Lebong dalam pengawasan yang jumlah Tenaga Kerja (TKA) Asing pada ahkir Bulan Tahun 2017 dapat dilihat pada table dibawah ini:

Tabel: Tenaga Kerja Asing Pada Akhir Tahun 2017

\begin{tabular}{|lll|}
\hline NO & \multicolumn{1}{c|}{ Bulan/Tahun } & \multicolumn{1}{c|}{ Jumlah Tenaga Asing } \\
1 & July 2017 & 55 Orang Tenaga Kerja Asing \\
2 & Agustus 2017 & 54 Orang Tenaga Kerja Asing \\
3 & Desember 2017 & 51 Orang Tenaga Kerja Asing \\
\hline
\end{tabular}

Sumber: Dinas ketenagakerjaan dan Transmigrasi Kabupaten Lebong, 2017.

Dari tabel di atas dapat dilihat jumlah Tenaga Kerja Asing yang berada di Kabupaten Lebong sebanyak 160 (Seratus Enam Puluh) orang yang terdaftar pada Dinas Ketenagakerjaan Dan Transmigrasi di Kabupaten Lebong.

Dalam penerimaan serta syarat Tenaga Kerja Asing dapat berkerja di Kabupaten Lebong dari kementerian lalu direkomendasikan kepada Dinas Ketenagakerjaan Provinsi. Dinas Ketenagakerjaan kabupaten hanya menerima Tenaga Kerja Asing yang mau bekerja di perusahaan di Kabupaten Lebong dalam pelaksanaan dan pengawasan Tenaga Kerja Asing tersebut sekarang masih berkordinasi ke Imigrasi Provinsi dan Dinas Ketenagakerjaan Provinsi Bengkulu memerintakan Dinas Ketenagakerjaan Kabupaten Lebong untuk melakukan pengawasan.

Tenaga Kerja Asing yang bekerja di Kabupaten Lebong dari Tahun 2016 Tahun 2017 yang terdaptar pada Dinas Ketenagakerjaan Kabupaten Lebong yang berjumlah 55 (Lima Puluh Lima) orang Tenaga Kerja Asing, Bulan Agustus berjumlah 54 (Lima Puluh Empat) orang Tenaga Kerja Asing dan Desember 2017 berjumlah 51 (Lima Puluh Satu) orang tenga kerja asing yang terdapat di Dinas Ketenagakerjaan Kabupaten Lebong. ${ }^{10}$

10 Hasil Wawancara Dengan Deka Sulhul di Dinas Tenagakerjaan Dan Tramigrasi di Kabupaten Lebong Pada Tanggal 6 Februari 2018, Pukul 09.00 wib.

Peko Laksono, Pengawasan Perizinan Tenaga Kerja Asing 
Kewenangan Kabupaten Lebong dalam pengawasan Tenaga Kerja Asing yang melakukan pengawasan tersebut bukan kewenangan Kabupaten karena pengawasan sudah beralih ke Provinsi. Dalam pelaksanaan pengawasan terhadap Tenaga Kerja Asing di perusahaan yang berada di Kabupaten Lebong, Belum di bentuk secara resmi, Tetapi sebelum ketua Dinas Ketenagakerjaan yang baru. Dalam pelaksanan pengawasan yang di lakukan oleh Dinas Ketenagakerjaan, Dalam 1 (satu) bulan sekali untuk melakukan pengawasaan dan langsung terjun kelapangan atau ke perusahaan yang mempergunakan Tenaga Kerja Asing. ${ }^{11}$

Pengawasan yang dilakukan oleh Dinas Ketenagakerjaan di Kabupaten Lebong yang memperkerjakan Tenaga Asing di perusahaan, maka absen Tenaga Kerja Asing yang ada di perushaaan dan diambil dan di absen atau di cek satu persatu dari TKA dokumennya untuk memeriksa Tenaga Kerja Asing yang bekerja dan di periksa di tempat.

Bahwa pegawasan yang dilakukan dengan melihat paspor orang asing nya berlaku atau tidak keabsahaan orang asing yang ada di Kabupaten Lebong. Kalau melihat ada keanehaan di temukan di lapangan tentang orang asing, maka tim pora atau sekretaris akan melaporkan kepada imigrasi bengkulu. Dengan pengawasaan yang dilakukan oleh Tim Pora tidak mesti setiap bulan melakukan pengawasaan tetapi setahun sekali pengawasaan yang di lakukan oleh Tim Pora, perlu di ketahui banyaknya orang asing yang berwisata atau berkunjung cuman beberapa hari misalnya pada saat Perseroan Terbatas Pertamina Geotermal Energi (PT PGE) melakukan pengeboran maka Tenaga Kerja Asing melakukan pengecekan atau melihat pengeboran tersebut sehari atau dua hari saja. ${ }^{12}$

Kewenangan pemerintah dalam bidang izin itu berupa kewenangan bebas, dalam arti kepada pemerintah diberi kewenangan untuk mempertimbangkan atas dasar inisiatif sendiri, yang berkaitan dengan izin, misalnya pertimbangan tentang Kondisi-kondisi apa yang memungkinkan suatu izin dapat diberikan kepada pemohon, bagaimana mempertimbangkan izin tersebut, konsekuensi yuridis yang mungkin timbul akibat pemberian atau penolakan izin dikaitkan dengan pembatasan peraturan perundang-undangan yang berlaku dan prosedur apa yang harus diikuti atau dipersiapkan pada saat dan sesudah keputusan diberikan baik penerimaan maupun penolakan pemberian izin. Pengawasaan ketenagakerjaan merupakan unsur penting dalam perlindungan tenaga kerja, sekaligus sebagai upaya penegakan hukum ketenagakerjaan secara menyeluruh. Pengawasaan ketenagakerjaan dilaksanakan melalui dua pendekatan, yaitu preventif, edukatif, dan refrensif yustisia. Pada dasar nya kedua cara itu ditempuh sangat bergantung dari tingkat kepatuhan masyarakakat (pengusaha, pekerja/buruh, dan serikat pekerja/serikat buruh) terhadap ketentuan hukum ketenagakerjaan. Tindakan preverentif edukatif dilakukan jika memungkinkan dan masih adanya kesadaraan

11 Hasil Wawancara Dengan Widian Hartono,di Dinas Tenagakerjaan Dan Tramigrasi di Kabupaten Lebong Pada Tanggal 6 Februari 2018, Pukul 09.00 wib.

12 Hasil Wawancara Dengan Heryantoni di Kantor Kesatuan dan Politik, Pada tanggal 7 Februari 2018, pukul 09.45. wib.

Peko Laksono, Pengawasan Perizinan Tenaga Kerja Asing 
masyarakat untuk mematuhi hukum. ${ }^{13}$ Pengawasaan ketenagakerjaan dilaksanakan untuk menjamin pelaksanaan peraturaan ketenagkerjaan (Pasal 176 Undang-Undang Nomor 13 Tahun 2003 tentang Ketenagakerjaan). Dengan demikian, sasaran pengawasaan ketenagakerjaan ialah meniadakan atau memperkecil adanya pelangaraan undang-undang ketenagakerjaan sehingga proses hubungan industrial dapat berjalan dengan baik dan harmonis.

\section{Penegakan Hukum Terhadap Tenaga Kerja Asing Ilegal Yang Bekerja Di Wilayah Kabupaten Lebong Jumlah Tenaga Kerja Asing Yang Melakukan Pelanggaran}

Jumlah Tenaga Asing Di Kabupaten Lebong dan di Provinsi Bengkulu pada bulan Desember 2017 yang mana hanya terdaptar di Dinas Ketenagakerjaan Dan Transmigrasi Provinsi Bengkulu berjumlah Tenaga Kerja Asing 74 (Tujuh Puluh Empat), sedangkan di Kabupaten Lebong berjumlah Tenaga Kerja Asing yang terdaftar di Dinas Tenagakerjaan dan Tramigrasi di Kabupaten Lebong berjumlah 51 (Lima Puluh Satu) Orang Tenaga Kerja Asing. Maka dengan adanya Tenaga Kerja Asing tersebut adanya perbedaan jumlah Tenaga Kerja Asing yang telah melakukan pelanggaran dan tidak terdaftar di Dinas Tenagakerjaan dan Tramigrasi di Kabupaten Lebong yang berjumlah 23 (dua puluh tiga) orang yang tidak terdaftar di Dinas Tenagakerjaan dan Tramigrasi Kabupaten Lebong, hal tersebut kurangnya pengawasan yang dilakukan oleh pemerintah di wilayah Kabupaten Lebong.

Fungsi pengawasan merupakan suatu usaha atau rangkaian usaha yang dilakukan oleh seorang atau sekelompok orang untuk menjaga agar proses pekerjaan dapat berjalan sesuai dengan rencana yang ditetapkan. Salah satunya pengawasan izin Tenaga Kerja Asing yang bertujuan melakukan pengawasan, agar kemudian hari tidak adanya Tenaga Kerja Asing yang ilegal dalam melakukan pelanggaran terkait izin bekerja di Indonesia khususnya di Propinsi Bengkulu. Dalam ketentuan Peraturan Presiden Nomor 72 Tahun 2014 dalam Pasal 15 menjadi kewenangan di mana sejak Januari 2017 Undang-Undang Nomor 23 Tahun 2014 tentang Pemerintah Daerah, penyelengaraan pengawasaan ketenagakerjaan yang semula menjadi urusan Pemerintah Daerah Kabupaten/Kota dialihkan menjadi urusan Pemerintah Provinsi. Peraturan Badan Kepegawaian Negara nomor 48 tahun 2015 tentag Pelaksanaan Pengalihaan Pegawai Negeri Sipil Daerah Kabupaten/Kota yang menyelengarakan penggawasan ketenagakerjaan menjadi Pegawai Negeri Sipil Daerah Provinsi sehinga semua pengawasan di alihkan status kepegawaianya menjadi pemerintah provinsi yang sebelumnya kewenangan pengawasaan ada di kabupaten/kota masing-masing

Undang-Undang Nomor 13 Tahun 2003 tentang Ketenagakerjaan, pengaturan penggunaan Tenaga Kerja Asing (TKA) dimuat pada Bab VIII, Pasal 42 sampai dengan Pasal 49. Pengaturan tersebut dimulai dari kewajiban pemberi kerja yang menggunakan Tenaga Kerja Asing untuk memperoleh izin tertulis;

13 Loc, Cit.

Peko Laksono, Pengawasan Perizinan Tenaga Kerja Asing 
memiliki rencana penggunaan Tenaga Kerja Asing yang memuat alasan, Jenis jabatan dan jangka waktu penggunaan Tenaga Kerja Asing kewajiban penunjukan tenaga kerja WNI sebagai pendamping Tenaga Kerja Asing hingga kewajiban memulangkan Tenaga Kerja Asing ke Negara asal setelah berakhirnya hubungan kerja.

Undang-Undang Nomor 13 Tahun 2003 tentang Ketenagakerjaan menegaskan bahwa setiap pengusaha dilarang mempekerjakan orang-orang asing tanpa izin tertulis dari Menteri. Pengertian Tenaga Kerja Asing juga dipersempit yaitu warga negara asing pemegang visa dengan maksud bekerja di wilayah Indonesia. Di dalam ketentuan tersebut ditegaskan kembali bahwa setiap pemberi kerja yang mempekerjakan Tenaga Kerja Asing wajib memiliki izin tertulis dari Menteri atau pejabat yang ditunjuk. Untuk memberikan kesempatan kerja yang lebih luas kepada tenaga kerja Indonesia (TKI), pemerintah membatasi penggunaan Tenaga Kerja Asing dan melakukan pengawasan. Dalam rangka itu, Pemerintah mengeluarkan sejumlah perangkat hukum mulai dari perizinan, jaminan perlindungan kesehatan sampai pada pengawasan.

Pelaksanaan Pengawasan terhadap Tenaga Kerja Asing yang diatur dalam Undang-Undang Nomor 13 Tahun 2003 tentang Ketenagakerjaan, dalam ketentuan Pasal 176, yang menyatakan bahwa:"Pengawasan ketenagakerjaan dilakukan oleh pegawai pengawas ketenagakerjaan yang mempunyai kompetensi dan independen guna menjamin pelaksanaan peraturan perundang-undangan ketenagakerjaan".

Selanjutnya dijelaskan dalam Peraturan Menteri Nomor PER.02/MEN/III/2008 Tentang Tata Cara Penggunaan Tenaga Kerja Asing, bahwa untuk memenuhi kebutuhan pasar kerja nasional terutama dalam mengisi kekosongan keahlian dan kompetensi di bidang tertentu yang tidak dapat ter-cover oleh tenaga kerja Indonesia, maka Tenaga Kerja Asing dapat dipekerjakan di Indonesia sepanjang dalam hubungan kerja untuk jabatan tertentu dan waktu tertentu. Mempekerjakan Tenaga Kerja Asing dapat dilakukan oleh pihak manapun sesuai dengan ketentuan kecuali pemberi kerja orang perseorangan. Setiap pemberi kerja yang mempekerjakan Tenaga Kerja Asing wajib memiliki izin tertulis dari menteri atau pejabat yang ditunjuk kecuali terhadap perwakilan negara asing yang mempergunakan Tenaga Kerja Asing sebagai pegawai diplomatik dan konsuler. Ketentuan mengenai jabatan tertentu dan waktu tertentu bagi Tenaga Kerja Asing ditetapkan dengan keputusan Menteri, yaitu Keputusan Menteri Nomor: KEP-173/MEN/2000 tentang Jangka Waktu Izin Mempekerjakan Tenaga Kerja Warga Negara Asing Pendatang.

Terhadap setiap pengajuan/rencana penggunaan Tenaga Kerja Asing di Indonesia harus dibatasi baik dalam jumlah maupun bidang-bidang yang dapat diduduki oleh Tenaga Kerja Asing. Hal itu bertujuan agar kehadiran Tenaga Kerja Asing di Indoesia bukanlah dianggap sebagai ancaman yang cukup serius bagi tenaga kerja Indonesia, justru kehadiran mereka sebagai pemicu bagi tenaga kerja Indonesia untuk lebih professional dan selalu menambah kemampuan dirinya agar dapat bersaing baik antara sesama tenaga kerja Indonesia maupun dengan Tenaga 
Kerja Asing. Oleh karenanya Undang-Undang Nomor 13 Tahun 2003 tentang Ketenagakerjaan, membatasi jabatan-jabatan yang dapat diduduki oleh Tenaga Kerja Asing. Terhadap Tenaga Kerja Asing dilarang menduduki jabatan yang mengurusi personalia dan/atau jabatan-jabatan tertentu yang selanjutnya diatur dengan Keputusan Menteri Tenaga Kerja dan Transmigrasi Nomor 223 Tahun 2003 tentang Jabatan-jabatan di Lembaga Pendidikan yang Dikecualikan dari Kewajiban Membayar Kompensasi.

Sesuai dalam ketentuan lampiran Keputusan Menteri Tenaga Kerja dan Transmigrasi Republik Indonesia Nomor 40 Tahun 2012 tentang Jabatan-Jabatan Tertentu Yang Dilarang Diduduki Tenaga Kerja Asing, sebagaimana dimaksud dalam ketentuan lampiran Keputusan Menteri Tenaga Kerja dan Transmigrasi Republik Indonesia Nomor 40 Tahun 2012, yaitu :

a. Direktur personalia.

b. Manajer Hubungan Industrial.

c. Manajer Personalia.

d. Supervisor Pengembangan personalia.

e. Supervisor Perekrutan personalia.

f. Supervisor Penempatan personalia.

g. Supervisor pembinaan personalia.

h. Penata usaha personalia.

i. Kepala Eksekutif Kantor.

j. Ahli Pengembangan Personalia dan karir

k. Spesialis personalia.

1. Penasehat karir.

m. Penasehat tenaga kerja.

n. Pembimbing dan konseling Jabatan.

o. Perantara Tenaga kerja.

p. Pengadministrasi Pelatihan Pegawai.

q. Pewawancara Pegawai.

r. Analisis Jabatan.

s. Penyelenggara Keselamatan Kerja Pegawai.

Sesuai dalam ketentuan lampiran Keputusan Menteri Tenaga Kerja dan Transmigrasi Republik Indonesia Nomor 40 Tahun 2012 tentang Jabatan-Jabatan Tertentu Yang Dilarang Diduduki Tenaga Kerja Asing. Selain jabatan yang tidak disebutkan dalam lampiran Keputusan Menteri Tenaga Kerja dilarang berkerja di Indonesia. Dengan adanya hal tersebut maka Jabatan-jabatan yang dilarang (closed list) ini harus diperhatikan oleh si pemberi kerja sebelum mengajukan penggunaan Tenaga Kerja Asing. Selain harus mentaati ketentuan tentang jabatan, juga harus memperhatikan standar kompetansi yang berlaku.

Walapun Tenaga Kerja Asing yang berkerja di Kabupaten Lebong sesuai dengan Jabatan-jabatan yang diduduki, akan tetapi masa jabatannya telah melanggar Pasal 42 ayat 6 Undang-Undang Nomor 13 Tahun 2003 tentang Ketenagakerjaan yang menyatakan bahwa Tenaga kerja asing sebagaimana 
dimaksud dalam ayat (4) yang masa kerjanya habis dan tidak dapat di perpanjang dapat digantikan oleh Tenaga Kerja Asing lainnya.

\section{Penegakan Hukum Terhadap Sanksi Tenaga Kerja Asing Yang Ilegal.}

Penegakan hukum adalah proses dilakukannya upaya untuk tegaknya atau berfungsinya norma-norma hukum secara nyata sebagai pedoman perilaku dalam lalu lintas atau hubungan-hubungan hukum dalam bermasyarakat dan bernegara. ${ }^{14}$ Masalah penegakan hukum adalah masalah yang universal. Tiap negara mengalaminya masing-masing, dengan falsafah dan caranya sendiri-sendiri, berusaha mewujudkan tegaknya hukum di dalam masayarakat. Tindakan tegas dengan kekerasan, ketatnya penjagaan, hukuman berat, tidak selalu menjamin tegaknya hukum. Apabila masyarakat yang bersangkutan tidak memahami hakekat hukum menjadi pedoman, maka hal itu akan menghambat hukum dan disiplin hukum. ${ }^{15}$

Berkaitan dengan penulisan skripsi ini, Penegakan hukum dalam mengawasi Tenaga Kerja Asing yang dilakukan di Kabupaten Lebong yang Undangundang Nomor 23 Tahun 2014 tentang Pemerintah Daerah, bahwa kewenagan dalam pelaksanaaanya dilakukan oleh pemerintah provinsi, dengan adanya kewenagan tersebut maka dilakukan oleh Tim PORA dalam mengawasi Tenaga Kerja Asing yang berada di wilayah Kabupaten Lebong data yang diperoleh dapat dilihat ditabel di bawah ini:

Tabel: Tenaga Kerja Asing pada ahkir Bulan Tahun 2017

\begin{tabular}{|lll|}
\hline NO & \multicolumn{1}{c|}{ Bulan/Tahun } & \multicolumn{1}{c|}{ Jumlah Tenaga Asing } \\
1 & July 2017 & 55 Orang Tenaga Kerja Asing \\
2 & Agustus 2017 & 54 Orang Tenaga Kerja Asing \\
3 & Desember 2017 & 51 Orang Tenaga Kerja Asing \\
\hline
\end{tabular}

Sumber: Dinas TenagaKerjaan dan Transmigrasi di Kabupaten Lebong, 2017.

Dari tabel di atas dapat dilihat jumlah Tenaga Kerja Asing yang berada di Kabupaten Lebong sebanyak 160 (Seratus Enam Puluh) orang yang terdaptar Dinas Tenagakerjaan Dan Tramigrasi di Kabupaten Lebong. Dengan adanya Tenaga Kerja Asing yang berkerja dan berada di Kabupaten Lebong, maka dalam dilakukannya pengawasan terhadap semua Tenaga Kerja Asing yang berkerja di Propinsi Bengkulu harus berpedoman dengan aturan peraturan perundangundangan yang berlaku. Terhadap Tenaga Kerja Asing tersebut yang mana ada perbedaan yang terdaftar Dinas Tenagakerjaan Dan Transmigrasi di Provinsi Bengkulu pada tahun 2017 yang berjumlah 74 (tujuh puluh empat) orang, Sedangkan di Dinas Tenagakerjaan Dan Transmigrasi di Kabupaten Lebong pada tahun 2017 berjumlah 51 Orang Tenaga Kerja Asing. Dengan adanya kesenjagan antara Dinas ketenagakerjaan Dan Tramigrasi di Provinsi Bengkulu dan Dinas

14.Jimly Asshiddiqie, penegakan hukum, makalah dalam www.jimly.com/makalah/namafile/56/Penegakan_Hukum.pdf, hlm.1

15 Soedjono, loc.it. hlm 75

Peko Laksono, Pengawasan Perizinan Tenaga Kerja Asing 
ketenagakerjaan Dan Tramigrasi di Kabupaten Lebong maka kurangnya pengawasan yang dilakukan oleh aparat pemerintah terhadapa Tenaga Kerja Asing yang ilegal tanpa memenuhi syarat untuk berkerja di wilayah Indonesia khususnya di Kabupaten Lebong. Dengan demikian penulis melakukan wawancara kepada ketua Tim Pora Kabupaten Lebong dan Dinas ketenagakerjaan Dan Transmigrasi di Provinsi Bengkulu terhadap pegawasan dan penegakan hukum bagi orang asing.

Bahwa tugas dan kewenangan dibentuknya fungsi Tim Pora di Kabupaten Lebong belum secara resmi dalam melakukan pengawasan orang asing. Mengenai kewenangannya Tim Pora menurutnya untuk memantau keberadaan orang asing atau Tenaga Kerja Asing ,terutama perusahaan yang mempergunakan Tenaga Kerja Asing yang ada di Kabupaten Lebong. 16

Tim Pora Kabupaten Lebong yang terdiri dari ketuanya berasal dari imigrasi bengkulu,Sekretaris nya berasla dari kepala Kantor Kesatuan Bangsa dan Politik (KESBANGPOL) Kabuapten Lebong dan angotanya berasal dari Provinsi, Sekretariatnya Tim Pora Kabupten Lebong berada di kantor kepala kepala Kantor Kesatuan Bangsa dan Politik kabupaten lebong. ${ }^{17}$ Dalam melakukan pengawasan orang asing dengan cara melihat paspor orang asing nya berlaku atau tidak keabsahaan orang asing yang ada di Kabupaten Lebong dengan melakukan tindak lanjut Tim Pora selama yang ada di lapangan, kalau melihat ada keanehaan di temukan di lapangan tentang orang asing, maka tim pora atau sekretaris akan melaporkan kepada imigrasi Bengkulu.

Pelaksanaan pengawasan Tim Pora berkala atau setiap setahun sekali atau rutin sebulan sekali dalam mengawasi Tenaga Kerja Asing di Kabupaten Lebong dilakukan pengawasan tetapi setahun sekali pengawasaan yang di lakukan oleh Tim Pora, perlu di ketahui banyak nya turis yang berwisata atau berkunjung cuman beberapa hari misal nya pada saat PT PGE melakukan pengeboran maka Tenaga Kerja Asing melakukan pengecekan atau melihat pengeboran tersebut sehari atau dua hari saja.

Sanksi terhadap TKA ilegal lebih kepada deportasi yang dilakukan oleh bagian Imigrasi sekali lagi TKA ilegal dalam undang-undang ketenagakerjaan merupakan saksi utama dan bukti nyata pelangaran yang dilakukan perusahaan pemberi pekerjaan yang memperkerjakan TKA tidak sesuai ketentuan sehingga pada tahap penindakan pidana oleh ppns ketenagakerjaan apabila TKA di pulangkan sebelum proses berita acara penindakan dilakukan maka akan menyulitkan dalam pencarian bukti dan sanksi dalam hal ini,undang-undang ketenagakerjaan tidak mengatur sanksi terhadap TKA ilegal tapi kepda perusahaan pemberi pekerjaan. ${ }^{18}$

Pelanggaran yang dilakukan oleh pekerja asing ditindaklanjuti dengan pengecekan, Pemeriksaan dan penindakan hukum sesuai ketentuan Perundangundangan jika sanksi untuk Tenaga kerja asing yang melangar adalah deportasi, Sanksi untuk perusahaan atau pemberi kerja yang melangar penggunaan TKA

\footnotetext{
${ }^{16}$ Hasil Wawancara Dengan Haryatoni, Op., Cit

17 Ibid.

${ }^{18}$ Hasil Wawancara Dengan Dewi Murni, Op., Cit.
} 
adalah hukum penjara dan denda sebagaimana di atur dalam Pasal 187 UndangUndang Nomor 13 Tahun 2003 tentang ketenagakerjaan.

Tenaga Kerja Asing yang sesuai ketentuan dalam penerbitan Izin Memperkerjakan Tenaga Asing ada penerimaan yang merupakan penerimaan bukan pajak yang berasal dari retribusi yang harus dibayar oleh TKA sejumlah $\$ 100 /$ bulan selama ia ada di Indonesia dan ini dibayarkan di muka dan menjadi Penerimaan Negara ${ }^{19}$ (Peraturan Pemerintah Nomor 97 Tahun 2012 Pasal 15). Maka di Provinsi Bengkulu mengenai hal tersebut di atur dalam ketentuan Peraturan Daerah Provinsi Bengkulu Nomor 7 Tahun 2016 tentang Retribusi Perpanjangan Izin Memperkerjakan Tenaga Kerja Asing. Sedangkan di Kabupaten/kota belum memiliki Peraturan Daerah yang menyatakan penerimaan dari TKA masuk dalam pendapatan daerah sehingga pendapatan $\$ 100 /$ bulan/TKA yang merupakan kewajiban kompensasi dalam rangka menunjang upaya peningkatan SDM Indonesia, dimasukan dalam rekening Kementerian Ketenagakerjaan pusat, Selain itu TKA tetap dipotong pajak penghasilan dan wajib pula di daptarkan dalam perlindungan BPJS Kesehataan maupun ketenagakerjaan bagi TKA yang bekerja di Indonesia lebih dari 6 bulan. (Permenakertrans Nomor 02 Tahun 2004).

\section{PENUTUP}

\section{Simpulan}

Sesuai dengan tujuan penelitian ini hasil kajian menyimpulkan bahwa Pengawasan Tenaga Kerja Asing di Kabupaten Lebong dilakukan oleh Tim Pora. Namun tidak berjalan optimal, hal ini terjadi disebabkan oleh beberapa faktor yaitu yang pertama kurangnya Struktur hukum Pemerintah Daerah dalam Pengawasan terhadap Tenaga Kerja Asing, yang kedua tidak adanya keterbukaan antara perusahaan asing dengan Dinas Ketenagakerjaan mengenai data Tenaga Kerja Asing yang ada di Provinsi Bengkulu khususnya Kabupaten Lebong, yang ketiga kurangnya pengawasan dari Tim Pengawasan Orang Asing (Tim Pora) di Kabupaten Lebong dalam melakukan pengecekan terhadap yang ada di Kabupaten Lebong; Berkaitan dengan penegakan hukum mengenai Tenaga Kerja Asing yang illegal. Undang-Undang Nomor 13 Tahun 2003 tentang Ketenagakerjaan tidak mengatur tentang sanksi terhadap TKA ilegal tetapi lebih kepada deportasi yang dilakukan oleh bagian imigrasi, demikian pula tidak mengatur sanksi terhadap TKA ilegal tapi kepada perusahaan pemberi pekerjaan.

\section{Saran}

Pelaksanaan pengawasaan yang dilakukan oleh Dinas Ketenagakerjaan (Disnaker) khususnya yang berada di Kabupaten Lebong, sebaiknya dilakukan oleh Tim Pengawasan Tenaga Kerja Asing yang dapat melibatkan pengawasan ketenagakerjaan yaitu, PPNS (Penyidik Pegawai Negeri Sipil), imigrasi perizinan, penempatan Tenaga Kerja Asing yang dilakukan dalam satu Tahun 1 (satu) Tahun harus ada pengawasan yang dilakukan agar tidak mudahnya ilegal.

${ }^{19}$ Hasil Wawancara Dengan Eni Denti, Op., Cit.

Peko Laksono, Pengawasan Perizinan Tenaga Kerja Asing 


\section{DAFTAR PUSTAKA}

Alfandi, Safuan. 2000, Kamus Lengkap Bahasa Indonesia, Penerbit: Sendang Ilmu Solo.

Asshiddiqie, Jimly, penegakan hukum, makalah dalam www.jimly.com/makalah/namafile/56/ Penegakan_Hukum.pdf,

Denti, Eni (Dinas Ketenagakerjaan Dan Tranmigrasi Provinsi Bengkulu), 2018, Hasil wawancara, Bengkulu, tanggal 29 Januari.

Hadjon, Philipus M., 2002, Pengantar Hukum Administrasi Indonesia, Yogyakarta, Gajah Mada Press University.

Harian

Rakyat

Bengkulu,

http://harianrakyatbengkulu.com/ver3/2017/07/26/TKA-masih-

didomininasi-asal-cina-penyebaran-TKA-didominasi-sektor-pertambangan, diunduh pada tangal 29 september 2017,pukul 22.12 wib

Heryantoni (Kantor Kesatuan dan Politik), 2018, Hasil wawancara, Bengkulu, tanggal 7 Februari.

Husni, Lalu. 2001, Pengantar Hukum Ketanaga Kerjaan Indonesia, PT. Raja Grafindo Persada, Jakarta.

HR, Ridwan. 2016, Hukum Adminitrasi Negara Edisi Revisi, PT Raja Grafindo Persada, Jakarta.

Iskandar "Hukum Perizinan Sebagai Instrumen Pencegahan Kerusakan Sumber Daya Alam dan Lingkungan Hidup" diunduh tanggal 08 oktober2017 pukul 13.30 WIB dari http://suttaniskandaralam.blogspot.co.id/

Keputusan Menteri Tenaga Kerja dan Transmigrasi Republik Indonesia Nomor 40 Tahun 2012 tentang Jabatan-Jabatan Tertentu Yang Dilarang Diduduki Tenaga Kerja Asing

Keputusan Menteri Tenaga Kerja dan Transmigrasi Nomor 223 Tahun 2003 tentang Jabatan-jabatan di Lembaga Pendidikan yang Dikecualikan dari Kewajiban Membayar Kompensasi.

Khakim, Abdul. 2014, Dasar-Dasar Hukum Ketenagakerjaan Indonesia, Cetakan Ke 4 Edisi Revisi, Penerbit PT Citra Aditya Bakti, Samarinda.

Manulang, Senjun H., 1990, Pokok-Pokok Hukum Ketenaga Kerjaan Indonesia, Rineka Cipta, Jakarta.

Jakarta. Rhineka Cipta.

Marzuki, Peter Mahmud. 2005, Penelitian Hukum, Penerbit Kencana Prenada Media Group,Edisi Revisi, Jakarta.

Murni, Dewi (Dinas Ketenagakerjaan dan Tranmigrasi Provinsi Bengkulu), 2018, Hasil Wawancara, Bengkulu,tanggal 29 Januari.

Mertokusumo, Sudikno. 2005, Mengenal Suatu Pengantar, Yogyakarta, Liberty.

Peraturan Pemerintah Nomor 31 Tahun 2013 tentang Peraturan Pelaksanaan Undang-Undang Nomor 6 Tahun 2011 tentang keimigrasian.

Peraturan Presiden Nomor 72 Tahun 2014 tentang Pengunaan Tenaga Kerja Asing Serta Pelaksanaan Pendidikan dan Pelatian Pekerja Pendamping

Peko Laksono, Pengawasan Perizinan Tenaga Kerja Asing 
Peraturan Menteri Ketenagakerjaan Nomor 16 Tahun 2015 tentang Tenaga Kerja Asing

Peraturan Menteri Hukum dan Hak Asasi Manusia Republik Indonesia Nomor 50 Tahun 2016 tentang Tim Pengawasan Orang Asing

Peraturan Menteri Nomor PER.02/MEN/III/2008 tentang Tata Cara Penggunaan Tenaga Kerja Asing.

Peraturan Daerah Provinsi Bengkulu Nomor 7 Tahun 2016 tentang Retribusi Perpanjangan Izin Memperkerjakan Tenaga Kerja Asing.

Pramukti, Angger Sigit dan Meylani Chahyaningsih, 2016,"Pengawasan Hukum Terhadap Aparatur Negara, Pustaka Yustisia, Yogyakarta.

Prins, W.F dan R.Kosim Adisapoetra, 1983, Pengantar Hukum Ilmu Administrasi Negara, Jakarta, Pradnya Paramita.

Rusli, Hardijan. 2003, Hukum Ketenagakerjaan. Jakarta : Ghalia Indonesia.

Soedjono, 1978, Penegakan Hukum dalam Sistem Pertahanan Sipil, Bandung, karya Nusantara.

Soemiro, Ronny Hanitijo, 1982, Metodologi Penelitian Hukum , Jakarta: Ghalia Indonesia.

Sinamo, Nomensen. 2015, Hukum Adminstrasi Negara, Jala Permata Aksara, Jakarta.

Spelt, N.M dan J.B.J.M. ten Berge,1993, Pengantar Hukum Perizinan, Surabaya, Yuridika.

SS, Adil. 2016,Dasar-dasar Hukum Bisnis, CV. Mitra Wacana Media, Jakarta.

Sunggono, Bambang. 2015, Metodologi Penelitian Hukum, Rajawali Pers, Jakarta.

Sulhul, Deka (Dinas Tenagakerjaan Dan Tramigrasi di Kabupaten Lebong), 2018, Hasil wawancara, Bengkulu, Tanggal 6 Februari.

Suratman dan Philips Dillah, 2012, Metode Penelitian Hukum, Penerbit Alfabeta Bandung.

Tutik, Titik Triwulan, 2010,Pengantar Hukum Tata Negara, Prestasi Pustaka, Jakarta.

Undang-Undang Nomor 6 Tahun 2011 tentang Keimigrasian

Undang-Undang Nomor 13 Tahun 2003 tentang Ketenagakerjaan

Undang-Undang Nomor 23 Tahun 2014 tentang Pemerintah Daerah 